\title{
Fotoperiodismo y etnografía: el caso de W. Eugene Smith y su proyecto sobre Deleitosa
}

\section{STANLEY BRANDES}

Departamento de Antropología

Universidad de California en Berkeley
JESÚS M. DE Miguel

Departamento de Sociología Universidad de Barcelona

Gracias a W. Eugene Smith (1918-1978) Deleitosa es seguramente el pueblo español más famoso en el mundo. "Los americanos" llegaron a ese lugar de Cáceres el 8 de junio de 1950, con un coche, una Leica, y un salvoconducto de la Embajada Española en París. En 19 días de trabajo de campo W. Eugene Smith - con la ayuda de Ted Castle como chófer/ ayudante, y de Nina Peinado como intérprete- sacó varios miles de fotografías, y produjo un reportaje fotográfico legendario que se publicó en la revista ilustrada norteamericana Life ${ }^{1}$.

Eran los tiempos en que la televisión no existía (estaba a punto de introducirse) y el mundo entero conocía al resto de la humanidad a través de las revistas ilustradas. Igual que el documental Tierra sin pan, de Luis Buñuel sobre Las Hurdes en Cáceres - no muy lejanas a Deleitosa- el reportaje de Smith llamaba la atención sobre la España negra, anclada en el pasado, retrasada, fatalista, nacionalcatólica, dictatorial, medieval casi, que vivía entre pobreza secular y fe ultramontana ${ }^{2}$. A su vez, el paralelismo de la película Bienvenido Mister Marshall, de Luis García Berlanga, dos años después, sobre un pueblo castellano ficticio - Villar del Río- que se transforma en andaluz para recibir a "los americanos", es algo más que coincidencia ${ }^{3}$.

1 Tenemos que agradecer a los herederos de W. Eugene Smith y al Black Star, Inc., su representante, por brindarnos el permiso para publicar las fotos. Hemos de agradecer también al Center for Creative Photography, en The University of Arizona (Tucson, Estados Unidos) la posibilidad de consultar el archivo de W. Eugene Smith y otros materiales bibliográficos. Este estudio es parte del proyecto PGC PB96-1238 del Ministerio de Educación y Cultura español. Muchas gracias a Carolina G. de Miguel por sus excelentes comentarios y correcciones; y a Antonio Tebar por su ayuda técnica.

2 El documental de Buñuel es del año 1932, con sonido y explicaciones en francés. Se realiza diez años después de la famosa visita de Alfonso XIII a Las Hurdes acompañado del médico Gregorio Marañón (véase Fundación Gregorio Marañón, ed. 1993).

3 Película en blanco y negro de 1953, de 75 minutos. El guión es de J. Antonio Bardem, Luis García Berlanga, y Miguel Mihura. Los actores principales son Lolita Sevilla, Manolo Morán y Pepe Isbert. 
W. Eugene Smith buscaba un pueblo cualquiera, una comunidad que expresase de forma sintética su idea de esa España peculiar de hace medio siglo. Después de mucho buscar, encontró el pueblo a 228 kilómetros de Madrid, en Cáceres, antes de llegar a Trujillo, en una desviación de la carretera de Extremadura ${ }^{4}$. Le llamó la atención su nombre: "Deleitosa" y la traducción que seguramente le dio su joven intérprete: delightful, a delightful place.

El pueblo de Deleitosa cuenta así con el raro privilegio de haber sido fotografiado hace medio siglo, de forma exhaustiva, por uno de los mejores fotógrafos internacionales. Tiene la ventaja de haber sido observado, publicado, discutido en el mundo entero. Pero todavía en la actualidad es un pueblo en que no pasa nada, nunca ocurre nada importante; salvo las visitas ocasionales y fugaces de admiradores de Smith que vienen al pueblo para no saber luego qué fotografiar. "Vienen de todo el mundo", nos cuentan en el pueblo "hasta de Argentina. Muchos americanos". Las fotos de Smith decoran ahora la Sala de Juntas del Ayuntamiento de Deleitosa, en blanco y negro, flanqueando una foto oficial en color desteñido del rey Juan Carlos I 5 .

Cincuenta años después Deleitosa continúa siendo un pueblo pequeño - ahora es tres veces más pequeño en población que en tiempos de Smith-, algo abandonado de la mano de Dios, pobre, sin alicientes culturales, apartado de los avances del mundo moderno. Las antiguas casuchas son ahora casas un poco mejores; los portones de recia madera se han sustituido por funcionales puertas de aluminio y vidrio (uno de los pequeños negocios locales); y bastantes casas exhiben en sus tejados antena parabólica. Otras casas están abandonadas, semiderruidas, a menudo convertidas en corral improvisado. Pero se ven muchas casas nuevas, y otras reformadas. Algunas de las mejores casas están cerradas, con las persianas bajadas, y con cartones entre las puertas de aluminio y cristal para que la luz no penetre y evitar así que estropee el suelo del recibidor. Son casas de hijos del pueblo que ya no viven en Deleitosa, salvo en las fiestas más señaladas y sobre todo en el verano. Hay también muchas casas con fachadas de yeso, y otras con ladrillo. A lo largo de la carretera se han construido bastantes chaletitos o casas de veraneo. No da la apariencia de un pueblo que haya disminuido en tamaño, más bien lo contrario. Aunque lo más llamativo es que una buena parte de las casas

4 Véase el mapa topográfico 680-II a escala 1:25.000 del Instituto Geográfico Nacional (1997).

5 Falta alguna foto que se ha debido llevar ya alguien, dejando el clavo y el espacio. "El libro" con el reportaje de Smith también ha desaparecido del Ayuntamiento. 
- sobre todo las mejores- están vacías. Hay como tres pueblos: las casas de veraneantes, las casas de los que realmente viven a diario, y las casas derruidas que se utilizan a veces como corral. Representa pues un tejido arquitectónico estratificado como consecuencia de tres etapas diferentes. Salvo la iglesia no hay edificios singulares antiguos.

La población actual, bastante envejecida, vive fundamentalmente de la Seguridad Social, del subsidio de paro, y de los múltiples bares que tiene el pueblo. Sigue habiendo iglesia, ahora remozada, pero ya no hay cine. Se está construyendo un centro cívico/cultural nuevo. Se construyó un "polideportivo", con una pequeña piscina municipal, que en verano se llena con los hijos de los que emigraron del pueblo, y cancha de fútbol-sala. En las fiestas de agosto - cuentan orgullosos los del pueblo- una vez vino el cantante Manolo Escobar. Cerca del cementerio hay ahora una miniplaza de toros. En la carretera, en la entrada del pueblo, Mirabreña es un nuevo restaurante especializado en bodas, comuniones, y bautizos ${ }^{6}$. A las afueras, en un altillo a mil pasos del pueblo, se reconstruyó por fin en 1972 la ermita de Los Mártires (destruida durante la Guerra Civil) transformándola en la ermita de Nuestra Señora de la Breña, patrona de Deleitosa (Quijada 1998). La Virgen tiene una excelente vista del pueblo a ojo de pájaro. El cementerio, al sur, no se ha movido de sitio.

Sólo a través de la fotografía es posible, por ejemplo, tener una imagen de cómo era Deleitosa hace medio siglo. La fotografía suele suponer un conocimiento distorsionador y selectivo de la realidad social. La fotografía es inquietante, ubicua, y admite interpretaciones múltiples. Pero es un forma ingeniosa de conocer la realidad social. De 1950 sólo nos quedan las escenas que el ojo derecho de W. Eugene Smith enfocó, a través de su Leica. Es necesario reconocer que a menudo el enfoque realizado por la cámara, así como la interpretación de cualquier imagen, son ideológicas (Buxó y de Miguel, eds. 1998). La visión de Smith es además una realidad en blanco y negro, no en color.

El presente artículo es parte de un trabajo de campo realizado entre Estados Unidos (el Center for Creative Photography en The University of Arizona) y Deleitosa, medio siglo después del proyecto de Smith. Su tarea consiste en ir midiendo la estructura y el cambio social de una comunidad a través de las décadas. Su formato trata de combinar fotografía y texto como estrategia para el análisis de la realidad social. Su objetivo es incorporar a las ciencias sociales los avances realizados por la fotografía.

- En el trabajo de campo de abril de 1998 fotografiamos detalladamente en Mirabreña una boda local con unos cuatrocientos invitados. Al final, aparecieron cincuenta invitados más de los previstos y tuvieron problemas serios de sillas. 
Volver a Deleitosa, cada medio siglo, permitirá saber algo más de la evolución de la sociedad española, del cambio social, así como del posible uso de la fotografía y de la imagen para entender la realidad social.

\section{EUGENE SMITH EN ESPAÑA}

Hace medio siglo, en 1950, el famoso fotoperiodista norteamericano W. Eugene Smith, empleado por la revista Life, realizó su sueño. Consiguió por fin el permiso de Life $-\mathrm{y}$ por lo tanto, los fondos necesariospara realizar un proyecto fotográfico de un pueblo español. Smith se trasladó de inmediato desde Gran Bretaña (donde estaba sacando fotos de los comicios electorales) a París, ciudad en la que esperaba encontrar un intérprete de español y alguna carta de introducción para entrar en España. Había oído hablar de un pintor, Joaquín Peinado, que era bilingüe y que seguramente estaría interesado en el proyecto. Peinado era un español exiliado por el franquismo; pero se negaba a regresar a España mientras Franco estuviese vivo. En su lugar recomendó a su hija, Nina, por entonces una chica de veinte años de edad, con un buen dominio del español, francés, e inglés. Peinado y Smith se pusieron pronto de acuerdo en las condiciones del trabajo. En mayo de 1950, junto con Ted Castle -fotógrafo, chófer y ayudante de Smith- salieron los tres para España en un viejo studebaker que compró la revista Life. Durante todo el viaje, el coche les causó numerosos problemas, aunque sirvió para que los tres escapasen finalmente de Deleitosa —el día de San Fermín de 1950 - con los carretes de fotos (negativos) escondidos en la parte inferior del coche para evitar que fueran requisados por la guardia civil.

Antes de salir de París, Smith había dado un paso importante. Consiguió de la Embajada de España en Francia una carta, redactada precipitadamente, firmada por el primer secretario de Embajada. La carta era un verdadero salvoconducto: "La Embajada de España en París, saluda muy atentamente a las Autoridades civiles y militares españolas y les agradecerá vivamente faciliten el viaje de Mr. Smith, súbdito norteamericano, quien se dirige a España, debidamente autorizado por el Ministerio de Asuntos Exteriores, con objeto de realizar un reportaje fotográfico y provisto del material necesario para el mismon. El documento, con fecha 2 de mayo de 1950, llevaba dos sellos oficiales, de vital importancia en aquellos años. Tres días después entraron por la frontera vasca y se dirigieron a San Sebastián, Guernica y Pamplona. Smith consideró, con razón, que sus posibilidades de fotografiar en España se debieron a esa carta. Más tarde cuenta en un reportaje a Life, que era mi carta, afortunada y mal interpretada, la que me permitió la libertad de fotografiar. 
Smith todavía no sabía bien por dónde empezar a fotografiar. En Barcelona y Málaga sacó algunas fotos de prueba sobre pobreza, otras sobre agricultura y alimentación. Durante un mes (hasta el 8 de junio, fecha en que "descubren" Deleitosa), viajaron por casi todo el país, pasando primero por el País Vasco, parando en Guernica, después Zaragoza y Barcelona. Luego bajaron por la costa hasta Valencia. De Valencia, fueron a Madrid, y de nuevo hacia el norte hasta Burgos. Buscando el pueblo español "ideal" condujeron por las carreteras nacionales de la época a Ciudad Real, Granada, Málaga, Sevilla, y Madrid. Después de otra salida fallida (el coche se les estropeó en la carretera) volvieron a Madrid. Finalmente, en la carretera hacia Extremadura Smith encontró el pueblo: un lugar de Cáceres que se denomina Deleitosa, entre Navalmoral de la Mata (a 55 kilómetros) y Trujillo (a 40 kilómetros), dependiendo económicamente más del primero. Refiriéndose a Smith, su ayudante - Ted Castlerecuerda: "Buscaba un sitio determinado. Buscaba un sitio con colinas desde donde pudiera conseguir las imágenes fotográficas que quería, y también una iglesia bonita que destacase visualmente. Tenía unos criterios, y Deleitosa los satisfacía" (citado en Hughes 1989: 252; originalmente en inglés).

Puesto que Deleitosa no tenía hotel ni pensión, Smith, Castle y Peinado iban y venían todos los días desde Trujillo, a una hora en coche del pueblo ${ }^{7}$. Desde el principio, la Guardia Civil de Deleitosa sospechó los motivos de los tres e intentó echarles del pueblo lo más pronto posible. Con ese fin, la Guardia Civil consultó a las autoridades en Cáceres, quienes les dieron a entender que no podían hacer nada mientras Smith tuviese permiso del gobierno central para fotografiar. El permiso dependía de la carta que Smith había conseguido de la Embajada de España en Francia.

Con razón la Guardia Civil sospechaba. Antes de salir para España, Smith escribió una carta a su mujer en que decía: "Voy a intentar entrar en un pueblo español, y documentar hasta el máximo la pobreza y el miedo causados por Franco. He tenido que engañar a Life de que sabía algo de español. Espero que sea el ensayo más importante de mi vida". Cuando Smith entró en España, el Congreso estadounidense estaba precisamente considerando, por primera vez desde la Guerra Civil, otorgar al gobierno de Franco un préstamo de unos cincuenta millones de dólares. Smith estaba en contra de cualquier acuerdo entre Estados Unidos y Franco,

7 Todavía no existe pensión u hotel en Deleitosa, aunque se puede conseguir alguna habitación en el bar/restaurante Avenida. Durante el trabajo de campo realizado en abril de 1998 nos alojamos en el parador nacional en Trujillo, viajando en coche alquilado a Deleitosa cada día. 
e intentó influir en la política norteamericana mediante su cámara fotográfica. Pensaba que el público de los Estados Unidos se pondría definitivamente en contra del préstamo si se daba cuenta de las consecuencias de la dictadura a través de sus fotos. Smith escribe sobre su reportaje a Life: "El préstamo a Franco, ahora bajo estudio en los Estados Unidos, pienso que es para la compra de fertilizante. La gran mayoría de personas con las que he hablado cree que [...] cualquier préstamo de los Estados Unidos no sería beneficioso para el pueblo español, sino que sería malgastado por la ineficacia y el soborno administrativos [...] Un préstamo es claramente un insulto para esta gente oprimidan. En realidad, sólo las autoridades de Deleitosa, es decir las personas que observaban a Smith de cerca, día tras día, dudaron de la inocencia de su proyecto fotográfico. Las autoridades franquistas se lo creyeron.

Pero al final, Franco obtuvo el préstamo estadounidense y Smith realizó uno de los grandes éxitos de su carrera como reportero fotográfico. Spanish Village: It Lives in Ancient Poverty and Faith - Un pueblo español: Vive en pobreza y fe seculares" se titula el ensayo fotográfico de Smith- se publicó en Life el 9 de abril de 1951. Smith manifestó en una carta a su madre su ansiedad ante la posibilidad de una interpretación equivocada de su ensayo fotográfico: "Con toda probabilidad, a los de Life les va a gustar el ensayo, y según la política del momento el ensayo puede resultar como un largo pretexto a favor de un préstamo a España - eso sería una especie de burla de mi trabajo que me llevaría a dimitir" (Archivo W. Eugene Smith, Caja 33:1). En su reportaje final a Life, explica a los directores de la revista: "Para elegir el pueblo de Deleitosa, conduje casi diez mil kilómetros, intentando seleccionar un pueblo que mostrara un panorama equilibrado. No se cuenta entre los pueblos más ricos, y definitivamente no es el pueblo más pobre que pude ver. También al elegir los temas dentro del pueblo, procuré lograr una visión equilibrada y no mostrar lo peor. Al ver las fotos ahora, siento que me preocupaba demasiado por ser justo, puesto que no representan la verdadera pobreza que hay en España" (Archivo W. Eugene Smith, Caja 33: 17).

Desde un punto de vista artístico Smith recibió enormes elogios de sus compatriotas. El fotógrafo más importante y famoso en aquellas fechas, Ansel Adams, escribió en julio de 1951: "Trabajo maravilloso! Cuando lo vi, me enorgullecí de mi profesión. Nos involucramos en teoría, el comercio y la crítica; pero de repente aparece algo como Spanish Village y el verdadero foco del potencial fotográfico se renueva" (Archivo W. Eugene Smith, Caja AG 33: 17). Ralph Samuels, el decano del New York Institute of Photography, escribió a Life en abril de 1951, "Ha pasado muchísimo tiempo desde que observé un juego de fotos tan emocional- 
mente conmovedoras como las del reportaje de Eugene Smith sobre el pueblo español de Deleitosa [...] Elaborado con pies de fotos y texto inteligentes, el ensayo representa una exhibición y una historia tan completa de un sector importante del país como se podría realizar a través de años enteros de estudios y viajes" (ibid.).

Pero Smith se deprimió por su propia obra. Escribió a su madre en 1950: "Trabajo sobre España bastante mediocre, y no lo vas a creer pero una de las razones es que intentaba más de la cuenta ser justo - para que cuando protesten, porque les va a doler pero no me van a poder refutar" (Archivo W. Eugene Smith, Caja 33: 1). A pesar de su opinión, y la de sus compatriotas, como era previsible, el Gobierno español reaccionó ante el reportaje "Spanish Village" de manera furiosa. Tanto en la prensa como en el mismo pueblo, se mostraron ofendidos por la visión de España en la obra de Smith, una visión que ellos consideraban negativa pero que él mismo reafirmaba que era demasiado generosa ${ }^{8}$.

Por tratarse de un pueblo español de los años cincuenta, hay mucho en el "Spanish Village" de interés etnográfico. Durante su estancia corta en Deleitosa, apenas 19 días, Smith funcionó de cierta manera como un etnógrafo. Intentaba representar mediante imágenes fotográficas lo que él vio como la verdad, de la misma forma que el antropólogo procura representar la verdad a través de su texto. ¿Hasta qué punto podemos creer lo que vemos en las fotos de Smith? ¿Qué podemos aprender del proyecto en Deleitosa de este gran artista en la cima de su carrera profesional (a sus 42 años de edad) sobre las responsabilidades éticas del fotógrafo, ya sea fotoperiodista o antropólogo? Una fotografía no es sólo una ventana abierta al mundo, que describe con fidelidad "fotográfica" la realidad: es también un espejo que permite comprender mejor la mentalidad del fotógrafo. En "Spanish Village" se puede aprender no sólo de Deleitosa, sino de la mirada de un outsider - "el americano" - contemplando una realidad que le es extraña, pero que le preocupa.

8 Ha pasado medio siglo. El pueblo ahora disculpa la visión sesgada de Smith. Incluso una docena de fotos del reportaje (enviadas por la revista life, según nos informa el anterior alcalde) cuelgan ahora en las paredes de la Sala de Juntas del Ayuntamiento, junto a un jarrón con flores de plástico, una televisión con vídeo, y la tradicional foto del Rey de España (Juan Carlos I). El pueblo disculpa las fotos con el argumento de que Deleitosa era realmente así de pobre. Aunque hay en el tono de sus palabras un cierto reproche, que se mezcla con el orgullo de que un día ese pueblo - Deleitosa - fue importante; cuando vinieron "los americanos" como se refieren a Smith y colaboradores en el pueblo. 


\section{UN PUEBLO ESPAÑOL}

"Spanish Village" es uno de los ensayos fotográficos más paradigmáticos publicados en el siglo xx. Es lectura obligada en cualquier clase de fotografía, y seguramente lo seguirá siendo en el futuro. Apareció en Life el 9 de abril de 1951, entre las páginas 120 y 129 del número 15 del volumen 30 de la revista. Lleva como subtítulo "It Lives in Ancient Poverty and Faith" es decir "Vive en pobreza y fe seculares" ". "Spanish Village" contiene 17 fotografías: 16 corresponden a la primera selección realizada por el propio Smith entre unas 2.500 fotos. Una de ellas (la de la hilandera) fue escogida por la revista Life, por sus cualidades estéticas entre una segunda selección proporcionada también por Smith. Quince fotos llevan un texto de varias líneas ${ }^{10}$. Hay además una introducción de una página (46 líneas) que sirve como prólogo. El conjunto contribuye al impacto estético y documental del ensayo. "Spanish Village" está diseñado tanto para apreciar como para enseñar; es a la vez una obra de arte y un trabajo periodístico.

La introducción presenta la visión que Smith esperaba comunicar de un pueblo antiguo, pobre y aislado. No sabía que el pueblo estaba en ese año en el esplendor de su historia. Sus 2.650 habitantes es el máximo que ha llegado a tener, ya que hacia 1800 sólo tenía 190 habitantes, y en 1996 baja del millar. Smith está describiendo - sin saberlo- un pueblo en su mejor momento demográfico. El prólogo del reportaje (no sabemos hasta qué punto es de Smith y no de los editores de la revista) comienza: "El pueblo de Deleitosa, un lugar de unos 2.300 campesinos, está situado sobre la alta y seca meseta occidental que se llama Extremadura, aproximadamente a la mitad de camino entre Madrid y la frontera con Portugal. Su nombre significa 'delightful' [deleitoso], lo cual ya no es" ${ }^{11}$. La explicación actual de los del pueblo es que el nombre no proviene de un sitio delicioso, sino de "delito". Antiguamente, se construyó en Deleitosa un penal o prisión, un alcázar incluso, donde estaban

9 Ancient tiene aquí un significado de antigua, pero sobre todo de algo que dura mucho, que es secular. Sugiere que España está en 1950 como en la Edad Media, o que "ha avanzado poco desde los tiempos medievales" como señala el texto introductorio.

10 Dos de ellas, la foto 11 del joven con arado, y la 17 del velatorio no llevan epígrafe ni texto de pie de foto.

11 En 1950 el censo real de Deleitosa era de 2.650 habitantes. En 1998 el pueblo sólo tiene 981, es decir el $37 \%$ de sus habitantes medio siglo antes. 
encerrados "los deleitosos" es decir lo que habían cometido un delito (ver la discusión en Quijada 1998).

El prólogo del reportaje original continúa con detalles sobre la vida cotidiana de los vecinos, enfatizando su incomunicación: "Mucha gente de Deleitosa nunca ha visto un ferrocarril, puesto que el más cercano está a unas 25 millas de distancia." Se refiere quizás a la estación de Navalmoral de la Mata, ciudad de la que Deleitosa dependía-y depende- más que de Trujillo, patria de Pizarro, lugar menos comercial y más turístico ${ }^{12}$. "El correo llega en burro. El teléfono más cercano está a 12 millas y media en un pueblo vecino". Se refiere a Robledollano o Retamosa. "El sistema de conducción de agua en Deleitosa consiste todavía en el tipo de acueductos y pozos que el pueblo ha usado durante siglos. Aparte de la bañera de metal portátil que pertenece al médico, no existen sistemas sanitarios modernos, y las calles hieden a causa de los burros y cerdos". El prólogo termina afirmando que Deleitosa está "mal dotada por la naturaleza", que el pueblo ha sido "diezmado por las guerras" y que "vive en la pobreza - una pobreza compartida por casi todos y aliviada sólo por el trabajo estacional de la tierra y por la fe que sostiene a la mayoría de los deleitosanos desde la hora de la primera comunión hasta el simple funeral que señala el final de una vidaw.

Las 17 fotos de "Spanish Village" están presentadas de manera imaginativa en 10 páginas. Las imágenes de la vida del pueblo se enmarcan entre dos fotografías sobre el ciclo vital de los habitantes. Los formatos son todos diferentes, y están dispuestos con mucho cuidado, para dar una sensación de irregularidad, y al mismo tiempo llamar la atención. Smith decide no sólo contar la vida de un pueblo (español) sino de una familia cacereña: los Curiel $^{13}$. Esta es una estrategia muy típica del periodismo estadounidense, que tiende a ilustrar un contexto social a través de la experiencia individual de una persona, o mejor aún de una familia concreta.

La primera foto del reportaje, situada incluso antes del texto, ocupa una página entera (de esas grandísimas de la revista Life de antes). Representa el comienzo de la vida social de una persona a sus siete años.

12 Navalmoral de la Mata está en la desviación del kilómetro 182 desde Madrid, en la actual Autovía de Extremadura. Deleitosa está a 9 kilómetros de la desviación en el kilómetro 219 de la autovía. Hay 55 kilómetros para acceder a Navalmoral de la Mata, que es la ciudad de referencia. La zona de influencia de Deleitosa es pues grande, aunque económicamente poco productiva.

13 El apellido Curiel es muy común en el pueblo. Hay docenas de Curieles. En el cementerio hay bastantes lápidas con ese nombre, aunque ninguna de la familia que Smith fotografió. 


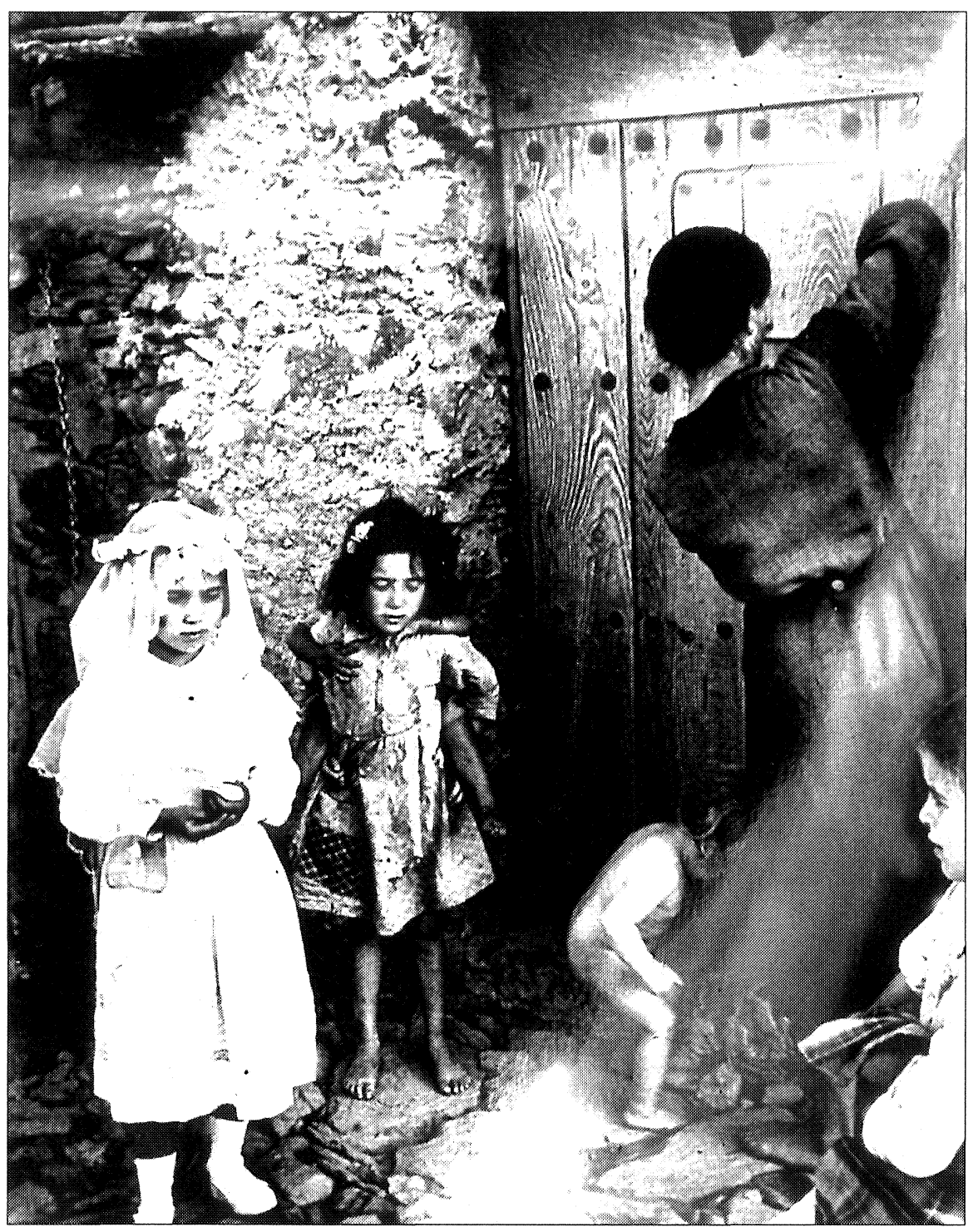

Se ve a una niña - Lorenza Curiel- vestida de blanco, a punto de ir a la iglesia del pueblo (la parroquia de San Juan Evangelista) para su primera comunión. Junto a ella aparecen cuatro niños. Uno está totalmente desnudo. Otra niña va vestida con un vestido sucio y remendado; lleva a caballito a un niño más pequeño también descalzo. Pero la niña lleva un adorno en el pelo. La cuarta niña apenas se ve, cortada tras la ampliación realizada por Smith. La niña vestida de primera comunión es la única que lleva zapatos (zapatos y calcetines blancos, sobre unas piernas 
bastante morenas); los otros aparecen descalzos. La madre, que aparece de espaldas, con un vestido oscuro y delantal (en donde destaca el botón central del cinturón), está cerrando la puerta de madera de la casa. La madre, que supuestamente va a llevar a su hija a la iglesia para la primera comunión, aparece también descalza. En la mayoría de las fotos sobre Deleitosa los niños aparecen en su mayoría descalzos, y muchas mujeres también. En cambio los varones aparecen siempre calzados, y el cura con zapatones.

En esta primera foto el suelo empedrado es muy irregular. La foto está realizada un poco en picado (desde arriba). Ninguna persona mira a la cámara. Lorenza Curiel aparece pensativa. En la parte de arriba de la foto se notan dos pitorros o aislantes de porcelana en el dintel de la puerta, lo que sugiere que la casa es una de las del pueblo que tiene luz eléctrica ${ }^{14}$. El pie de esta foto explica, "Vestida de Primera Comunión: Lorenza Curiel, 7, es admirada por sus jóvenes vecinos, mientras espera a que su madre cierre la puerta para llevarla a la iglesia" ${ }^{15}$. El contraste entre el vestido blanquísimo de primera comunión y los de los otros niños, el vestido oscuro de su madre, e incluso las piernas y manos oscuras de la propia Lorenza es un efecto estético importante - de contraposición- en la foto. Lo que más llama la atención es ver a un niño totalmente desnudo por la calle, aunque sea el mes de junio y en la soleada Extremadura. El broche y el collar que lleva Lorenza Curiel no son de niña pequeña; pero el vestido sí parece suyo, no prestado. Pobreza y religión, los dos grandes temas de Smith en este ensayo, son pues evidentes ya desde el principio del reportaje.

La última foto del ensayo ocupa dos páginas enteras. Es un velatorio. El difunto, un anciano, aparece sobre la cama con las manos juntas. Seis

14 En la introducción se señala que solamente la mitad de las 800 casas tienen luz eléctrica, siendo en realidad una instalación muy débil, seguramente de apenas una bombilla en esas casas afortunadas. En la fotografía 4 el médico aparece en la calle con una linterna (quizás de petróleo) para poder iluminar las casas de los pacientes cuando realiza visitas.

15 Hemos buscado esta puerta sin poderla encontrar. Es peculiar, pues tiene una ventana en la propia puerta (algo que se puede ver en otras puertas antiguas todavía en el pueblo) con un agujero circular. La madre parece cerrar la puerta a través de esa gatera (o agujero) superior. Quizás no está realmente cerrando. Es raro que en esos años, y en ese tipo de pueblo, las personas cerrasen realmente para ir a la iglesia. En cualquier caso hemos buscado la misma puerta incansablemente pero no hemos podido encontrarla. En el pueblo actualmente la mitad de las puertas antiguas ha desaparecido ya, siendo sustituidas por otras "modernas" de aluminio y vidrio, fabricadas en el propio pueblo por uno de los vecinos que tiene un pequeño negocio en la carretera principal. 


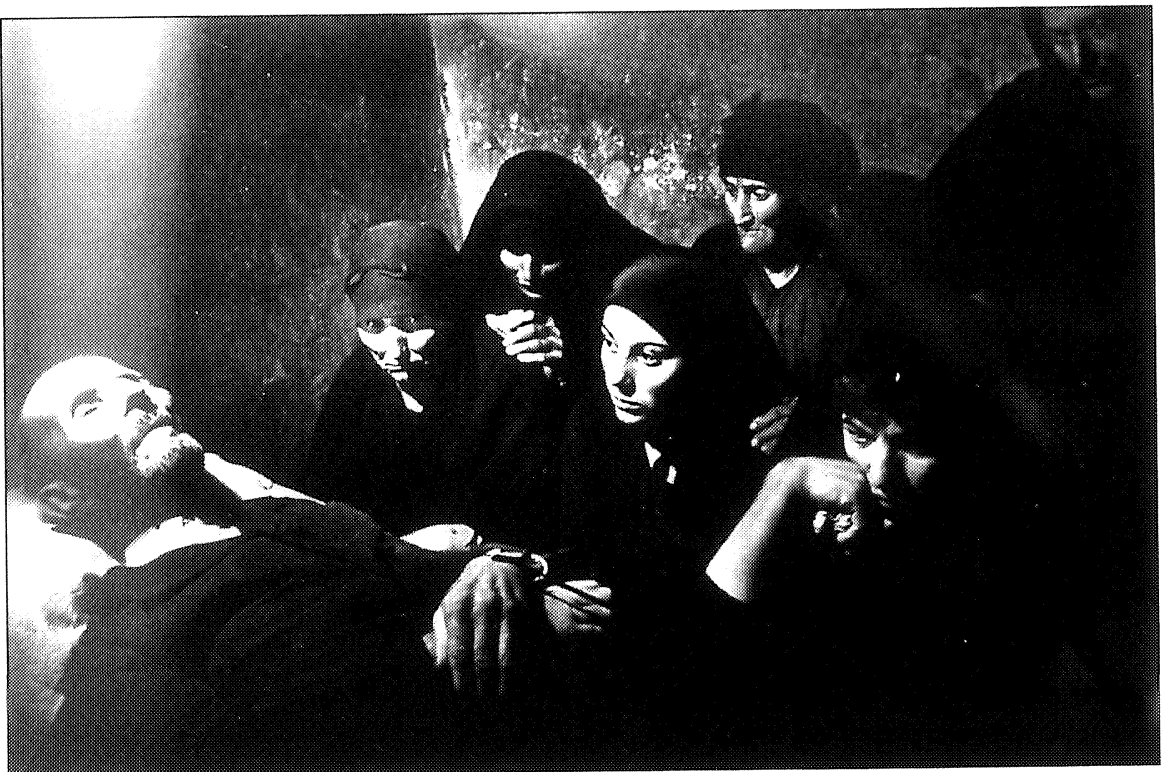

mujeres, vestidas de luto con el cabello cubierto, aparecen arrodilladas al lado. Todas tienen caras sombrías y dos de ellas llevan un pañuelo arrebujado en la mano. Las paredes del cuarto están mal cuidadas, o descascarilladas. La luz da sobre la cara del cadáver, y sobre la de las mujeres; el resto permanece casi en penumbra, resaltando la escena. Una de las mujeres mira a la cámara con cara algo siniestra. No hay pie de foto pero sí una leyenda que dice: «Su esposa, hija, nieta y amigos realizan su última visita terrenal a uno del pueblo". La nieta, en el centro, es de singular belleza ${ }^{16}$. No se ven símbolos religiosos, lo que llama la atención.

De nuevo, es una imagen fotográfica de pobreza y fatalismo. Así termina la vida, tal y como había empezado socialmente el día de la primera comunión. El reportaje de Smith sigue una típica estructura "de la cuna a la tumban bastante utilizada por los fotógrafos, y que se reproduce en la histórica exposición de The Family of Man cuatro años después (Edward Steichen ed. 1955) ${ }^{17}$. Willumson (1992: 115) señala que esta foto "resume

16 Uno del pueblo (el antiguo alcalde) nos cuenta que "el americano se enamoró de ella y se la llevón. Preguntado si se refería a "los americanos" (Smith y colaboradores) señala que no, que fue otro americano. Como puede verse la leyenda de la visión outsider del pueblo se magnifica. Parece ser que "el americano" se la llevó a Francia. Hay una cierta mitología en este pueblo sobre la migración a Francia, además de a Vitoria y Barcelona. No hemos podido averiguar aún el nombre de esta nieta, ni su paradero real.

17 Contiene 503 fotografías de 68 países. La última foto es precisamente de W. Eugene Smith, titulada "The walk to paradise garden" de 1946, en que aparecen un 
dramáticamente el tema destacado por todo el ensayo fotográfico: el contraste entre la pobreza material de los vecinos y la nobleza de su fuerza espiritual. El cadáver parece el de un hidalgo machadiano, pleno de honor. Las manos rudas, que en el caso de las mujeres sirven para consolar, juegan un papel destacado. Las mujeres parecen plañideras, vestidas de oscuro, aunque aparecen pensando más que llorando. Al igual que en la foto de la primera comunión lo que más llama la atención es la actitud pensativa, reconcentrada, de las personas del pueblo. En la primera, Lorenza Curiel, de siete años, parece estar pensando no sólo sobre su pasado sino sobre su futuro; en la última, el anciano muerto es contemplado por sus familiares en actitud meditativa. Smith no fue exitoso en representar el miedo de la población bajo el régimen franquista. Más bien la población aparece pensativa, sugiriendo una cierta riqueza mental interna.

Las demás fotos que constituyen "Spanish Village" muestran aspectos variados de la vida cotidiana de Deleitosa. Hay cinco imágenes fotográficas de procesos agrícolas: dividiendo el terreno para trillar (la 7), discutiendo sobre las parcelas (la 8), tiempo de sembrar (9), aventando el grano (10), y joven con arado romano (11). El tema religioso aparece en la foto del "Señor cura" (sic en castellano, la foto 6), que es una imagen en picado de Don Manuel caminando por una calle empedrada, asiendo un fuerte bastón ${ }^{18}$. Otra foto es la de un bautizo en que vuelve a aparecer el mismo párroco (15).

Los temas de producción agrícola y alimentación interesaban a Smith, pues la excusa inicial era realizar un reportaje sobre los problemas de producción agraria y de alimentación en España. En "Spanish Village" se publica otra foto, que ocupa una página entera, de una joven de 18 años - Bernardina Curiel, precisamente hermana de Lorenza, la niña de la primera comunión - que lleva sobre la cabeza una tabla llena de hogazas amasadas para cocer en el horno comunal del pueblo (foto 3). Las cincuenta hogazas de pan tampoco dan precisamente la imagen de hambre que Smith pretendía resaltar en el reportaje.

Otra foto más pequeña, algo desenfocada, pero importante (la 13) presenta la hora de la cena de la familia Curiel. Es una foto en picado, la familia junta cenando en casa, casi en cuclillas o en sillas muy bajas

niño y una niña, de la mano, de espaldas, caminando hacia un claro del bosque, en Estados Unidos. Es una alegoría del futuro esperanzado del sueño americano (American dream) de aquellos años.

18 Con exactitud etnográfica el pie de foto señala que Don Manuel tiene 69 años. En la actualidad da nombre a una calle al lado de la iglesia del pueblo: "Calle Párroco D. Manuel. 
alrededor de la olla puesta sobre el suelo. El matrimonio y los cuatro hijos se arriman para comer de la misma olla, sin platos, pero con varias cucharas. Por el reportaje se conoce el nombre de tres hijos: Bernardina de 18 años (la que lleva los panes a cocer en la foto 3), Lorenza de 7 años (la niña de la primera comunión de la primera foto), Lutero de 5 años (el niño recogiendo excrementos en la foto 5), y un niño intermedio, quizás de 10 ó 12 años (de quien no se conoce el nombre) sentado entre Lutero y Bernardina ${ }^{19}$.

Entre las demás fotos están las de un niño recogiendo excrementos de animales en la calle, un aula de niñas en la escuela del pueblo, una mujer hilando vestida de negro, y un retrato de tres guardias civiles. Para su reportaje de Life, parece que Smith presentó a la revista 113 fotos, ya reveladas, cortadas y ampliadas, de las cuales los directores eligieron 17 para componer 10 páginas. En su selección, los directores siguieron la idea que tenía Smith, y la división original en media docena de temas. En un análisis sobre "Spanish Village", Glenn Willumson (1992:113) explica: "Buscando las cualidades compartidas de esas fotografías, uno observa que los

19 Suponemos pues que los cuatro hijos tienen edades de 5, 7, 11, y 18 años. Parece una pauta rara de nacimiento, pues hay un espaciamiento anómalo entre la primogénita y la segunda hija. Pero es fácilmente explicable si se tienen en cuenta los años exactos de nacimiento: en 1932 nace Bernardina, en 1939 Lorenza, en 1943 el niño cuyo nombre no conocemos pero que vamos a llamar Demetrio, y en 1945 Lutero (en realidad Eleuterio). Bernardina nace antes de la Guerra Civil. La contienda hace que los padres retrasen el resto de los nacimientos hasta el año 1939, al final de la guerra, en que nace Lorenza. Demetrio y Eleuterio nacen luego en lo que se denominan "los años del hambre": 1943 y 1945. Esta cronología de hijos ilustra cómo debieron ser las dificultades y penalidades de esta familia Curiel, que retrasan siete años el primer intervalo intergenésico, una vez iniciada la crianza de la primera hija Bernardina. No es un caso insólito en esa época. El año de nacimiento de Lorenza, 1939, es de una elevada natalidad en España, coincidiendo con el final de la Guerra Civil. Lorenza - la chica de la primera comunión - representa así una nueva generación de españoles. Ella sería una informante clave para entender este reportaje. Según nuestras pesquisas, la familia podría ser la de Ponciano Curiel (el padre), Fidela (la madre) y sus hijos: Lorenza, Bernardina, Demetrio, y Eleuterio. Ya no están en el pueblo, y nadie da señales de ellos. Parece, un poco, una conspiración del silencio sobre esta familia. Los del pueblo señalan que la familia se fue a Francia. Un informante (S. A.) quien fue novio antes de una de las dos muchachas, parece saber algo más. Todo nos hace sospechar que la familia tuvo que abandonar el pueblo debido al oprobio que significó el reportaje, y que se centró mucho en esta familia Curiel (pues de ellos son las fotos 1, 3, 5, y 13 por lo menos). Analizar el control social que supuso expulsar simbólicamente del pueblo a esta familia sería un buen trabajo antropológico. Entrevistar a Lorenza (actualmente 55 años) o a su hermana mayor Bernardina (66 años en la actualidad) sería una tarea etnográfica y sociológica clave para entender mejor el proyecto de Smith. 
directores seleccionaron retratos de individuos aislados cuyos oficios e iconografía subrayan la pobreza del pueblo —un niño pequeño recoge estiércol de la calle para que sea usado como fertilizante en la parcela de su familia, y un médico visita a sus pacientes llevando una linterna de gasolina para iluminar los interiores tristes de las casas campesinas". Pero Willumson no señala algunos detalles interesantes: que el niño (de la foto 5) aparece descalzo recogiendo excrementos con un escobón sin mango ${ }^{20}$. Se trata de Lutero, el pequeño de cinco años, de la familia Curiel. Ya desde el principio nos sorprendió ese nombre, porque en España es un nombre prohibido en esos años, por ser protestante. Nadie se llama Lutero, y menos aún en un pueblo cacereño como el de Deleitosa en el año 1945. Los del pueblo actualmente nos señalaron la equivocación de Smith. —Ah, sí, Leuterio, Leuterio". Se refieren claro a Eleuterio ${ }^{21}$.

El tema de la religión también destaca entre las fotos publicadas; hay que recordar que "Spanish Village" empieza con la imagen de una primera comunión (foto 1), termina con la foto del velatorio (17), e incluye fotos significativas de un cura (6) y de un bautizo (15) ${ }^{22}$. El tema de la alimentación es también central en el reportaje de Smith; está representado por la portadora de hogazas de pan, la cena familiar y las cinco fotos de los procesos agrícolas. Life parece haber elegido fotografías bastante representativas de los intereses de Smith en cuestiones de pobreza, reli-

20 Todavía en la actualidad (trabajo de campo en abril de 1998) las escobas del pueblo no llevan mango o palo. Son exactamente como las de hace medio siglo: confeccionadas en casa, con ramas secas atadas con una cuerda. Para barrer, las mujeres tienen que agacharse, exactamente como en las fotos de Smith. Es impresionante que nada haya cambiado en ese medio siglo. En cambio las fregonas se compran industrialmente, y tienen palo, junto con sus cubos de plástico. Otro detalle de retraso es que la ropa se tiende a secar todavía delante de las casas, en una cuerda que se cuelga entre la puerta y una de las ventanas generalmente, pero sin que la cuerda sobresalga, es decir sin tendedero. La ropa queda así pegada directamente sobre la fachada de las casas, a nivel del ojo humano, exhibiéndose la ropa interior. No parecen haber descubierto un sistema de tendedero. Sin embargo, una buena proporción de casas tienen antena parabólica para conectar con emisoras de televisión por satélite.

21 Esto hace suponer que la intérprete no era muy avezada, y que equivocó el nombre de "-leuterio" del pueblo por el de "Lutero", nombre este último prácticamente imposible en España. Ninguno de los estudios anteriores se sorprenden de que un pequeño de 5 años pueda llamarse Lutero en España; ni detectan la equivocación. No estaba permitido un nombre protestante en un país ultracatólico en pleno franquismo, sobre todo el de Lutero. Ningún cura bautizaría a un niño con ese nombre.

22 El bautizado tiene actualmente 48 años, se llama Buenaventura Jiménez Morena, y trabaja en Correos en Getafe o Móstoles, en Madrid. Acude al pueblo de Deleitosa para las fiestas. 
gión y alimentación. Lo más importante es que todas son de seres humanos, y no simplemente fotos en donde hay personas, sino que esas personas están en acción, haciendo algo concreto. El protagonista es siempre el ser humano.

No se sabe hasta qué punto Smith ejerció su influencia sobre las decisiones de publicar ciertas fotos y no otras. En los 19 días que realmente pudo fotografiar en Deleitosa (como parte de su viaje a Trujillo y Deleitosa, desde el 8 de junio al 7 de julio de 1950) produjo unos 2.500 negativos. De ellos 1.620 (el 65\%) no fueron revelados hasta su vuelta a Londres una semana después (el 15 de julio). Los otros carretes los reveló en varios viajes a Madrid durante el propio trabajo de campo, por miedo a que cayesen en manos de la Guardia Civil. De estos negativos y contactos, reveló y amplió 57 que seleccionó como los más importantes. Incluye en esos 57 doce fotos de la familia Curiel. Se sabe que la revista Life escogió 16 de las 17 famosas fotos de esa primera selección (es decir el $28 \%$ de fotos). La otra foto - la hilandera- fue escogida de una segunda selección que también realizó Smith, que contenía 56 adicionales, a las que sólo había adjuntado una breve referencia.

Smith era un perfeccionista ${ }^{23}$. Demoraba la entrega de sus fotos hasta que estaba completamente satisfecho con ellas, un momento casi siempre más allá de la fecha tope de Life. Así se explica que el reportaje tardara diez meses en publicarse. Según un amigo y editor de Life, la revista había reservado unas catorce páginas para el reportaje de Deleitosa. Pero al no cumplir con la fecha tope, el ensayo se redujo a diez páginas (Hughes 1989: 265). Tampoco figuraba una de las fotos de Smith en la portada del número de Life en que apareció el reportaje, a pesar de sus sugerencias sobre las fotos que se adaptarían bien a la portada. Smith esperó seguramente más tiempo del preciso, quizás temeroso del impacto del reporta-

23 Smith pretendía conservar el control total sobre sus fotos y no entregaba los negativos, sino las ampliaciones realizadas por él mismo. En realidad la mayor parte de los negativos están cortados. Si se consultan los negativos enteros se observa que las decisiones de cortar no son nunca inocentes, como en la foto de la primera comunión (la 1), o en la que están tres del pueblo discutiendo sobre las parcelas (la 8). Ésta aparece muy torcida, debido a que el negativo le salió torcido. Quizás eso le enfadó, y le hizo exagerar aún más la inclinación al ampliarla, como una especie de venganza contra su propia torpeza. El manejo de esta foto 8 nos dice mucho del carácter de Smith. Otra foto muy cortada es la 12, la famosa de los tres guardias civiles, que aparece cortada por los cuatro lados (sobre todo por la derecha y arriba) precisamente para acentuar el carácter maligno de los tres guardias. La práctica de cortar los negativos en las ampliaciones es una conducta actualmente criticada entre fotógrafos profesionales, sobre todo los que se dedican a este tipo de fotorreportajes sociales. Supone una decidida falsificación de la realidad social. 
je, o simplemente insatisfecho. Su trabajo se mezcló también con problemas de salud, de los que tuvieron incluso que atenderle sanitariamente. Su editor artístico en Life, Bernard Quint, manifiesta que "Gene simplemente me presentó un montón de fotos, que eran exactamente 57 que él había elegido entre los centenares de fotos sacadas" (citado en Hughes 1989: 269). Quint explica en una entrevista el largo proceso por el cual tenía que convencer a Smith de incluir ciertas fotos y no otras en el reportaje, y cómo colocarlas en la página de la manera más artística y eficaz (ibid.: 270)

Un aspecto clave en cualquier reportaje fotográfico es el pie de foto. Como sugiere Mary Price (1994: 71): “Descripciones, o títulos descriptivos, ponen límites a las expectativas [de los lectores], dirigen la atención al sujeto o al contexto, quizás nombran fecha y lugar.. El pie de foto sirve para orientar a los lectores, y para ofrecerles una interpretación de la foto. También el texto proporciona información más allá de lo que se ve en la misma fotografía. Smith se cuidaba mucho de los pies de foto. Parece que eso contribuyó al retraso en la entrega del reportaje (Hughes 1989: 265).

Cada una de las fotografías de "Spanish Village" lleva un texto breve que comenta y amplía la información etnográfica de la misma foto. La del señor cura (6) es un retrato de cuerpo entero. Es un picado, está sacada desde arriba. Se ve al cura caminar por una calle empedrada. Lleva sotana y, en la mano izquierda, un recio bastón. Pero no se apoya en el bastón sino que lo lleva agarrado por debajo de la empuñadura, de forma amenazante. La foto se titula, "Senor cura" (sic con ene no con eñe) ${ }^{24}$. El texto explica: "De paseo, el cura del pueblo, Don Manuel, 69, pasa por delante de una ventana con reja y una puerta con cortina de una casa. Pocas veces se ha metido en política —el pueblo fue sangrientamente dividido durante la guerra civil- sino que se dedica a su ministerio. A los del pueblo les gusta estom. Sin embargo, el comentario es difícilmente aceptable. Conociendo la época y el pueblo, es altamente probable que el cura ejerciera una férrea autoridad religiosa y política dentro del pueblo. Además el comentario es el opuesto a lo que se observa en la imagen. Smith presenta a un sacerdote con sombrero negro de cura, con porte autoritario, muy diferente a la mayoría de los del pueblo que van descalzos y mal vestidos, sucios, y con remiendos. Parece que va fumando un puro. Don Manuel agarra el bastón con decisión, y en posición amenazante. Sus zapatones parecen botas. En nada ofrece la imagen de un ser

24 Los curas en esa época se trataban de "Don" (Don Manuel), o de "párroco", "cura", e incluso "padre" pero raramente de "Señor cura". Es una visión tópica de España que no se ajusta a la realidad. 
pacífico, dedicado solamente a temas de religión. Está clara la intención política de Smith al sacar la foto, y al incluirla como significativa entre las 57 más importantes. Sin embargo, el comentario de la revista Life es suave, el mensaje inverso al que sugiere la foto. En temas de dictadura el reportaje - y sobre todo la revista Life - es más duro que en temas de religión. La censura de Life parece obvia. Cuatro páginas más adelante, vemos al cura otra vez en una foto titulada "Un bautizo" (foto 15). El pie explica, "Mientras su padrino le sostiene en brazos encima de la pila bautismal, el cura Don Manuel seca la cabeza de Buenaventura Jiménez Morena, de un mes de edad, después de su bautizo en la parroquia". Se refiere a inmediatamente después, pues todavía están en la ceremonia del bautismo. Los familiares aparecen endomingados y el cura con bonete negro y roquete blanco. El cura es el único que lleva gafas en el pueblo además del médico (foto 4).

En los pies de foto, Smith repite varias veces la idea de espacio limitado, una condición no evidente por lo que se observa en las mismas imágenes. En "La escuela del pueblo" [Village schooll, la foto 14, aparece el aula de la escuela de niñas, con cuatro niñas atentas, sentadas en sus pupitres. Smith señala en el texto: "Las niñas van a clases separadas de los niños. Hay sólo cuatro aulas y cuatro maestros para enseñar hasta 300 alumnos en invierno, entre 6 y 14 años de edad. La foto no representa una condición masificada en el aula. Sin embargo, el pie informa de que en el pueblo de Deleitosa puede haber hasta 75 alumnos por aula "en invierno" (la especificación de "en invierno" es algo misteriosa), todos enseñados por un sólo maestro. Esta situación sería alarmante para los norteamericanos. La separación de niños y niñas en España es usual por lo menos hasta los años sesenta. En la foto, las niñas aparecen bien vestidas, en pupitres individuales, con tintero para escribir con plumilla, luz natural y libros encima de los pupitres. Desgraciadamente no se alcanza a ver si van descalzas. La foto proporciona una idea de dignidad, que el pie de foto transforma al sugerir sexismo y masificación. Es otro ejemplo de cómo el mensaje de la foto y del texto resultan divergentes. En la foto anterior, "Cena familiar" [Family dinner] Smith explica que "Los Curiel comen potaje [en sus palabras, thick bean and potato soup] de una sola olla sobre el suelo de tierra de su cocina. Padre, madre, y cuatro hijos comparten el único dormitorio" ${ }^{25}$. De nuevo, se destaca la idea de espacio limitado: comen todos juntos de la misma olla y duermen todos jun-

25 La foto 3 señala que los Curiel son una familia de ocho personas. No queda clara la discrepancia entre ambas informaciones. Quizás conviven con ellos unos abuelos que no aparecen en las fotos. 
tos. Pero van dignamente vestidos y el padre incluso con sombrero de paja dentro de casa. En realidad es una foto típica de pobreza digna.

La foto "Discutiendo sobre las parcelas" [Haggling over lots] muestra un hombre y dos mujeres en el campo, los tres pobremente vestidos. Se refiere a la discusión sobre las parcelas para trillar (la era) que les ha tocado seguramente en el sorteo o reparto comunal. El hombre gesticula con el brazo extendido; una de las mujeres tiene la boca (que carece casi por completo de dientes) abierta como si estuviera gritando. La otra mujer le mira y habla, como si le estuviera replicando. Una de las dos mujeres está descalza en mitad del campo. Los tres aparecen mal vestidos y con grandes remiendos. El pie de la foto 8 señala: "A veces la suerte da a una familia una era pedregosa para trillar, y a la otra una era limpia. Esto conlleva peleas, puesto que la era limpia facilita más la tarea de trillar. De nuevo Smith presenta la circunstancia del espacio limitado junto con una explicación de sus consecuencias en cuanto a las relaciones humanas. Las consecuencias, por supuesto, son negativas. La foto aparece muy inclinada, resaltando el escorzo del brazo izquierdo del varón. La consulta del contacto original del negativo demuestra que la foto está alterada, y que la inclinación fue aumentada considerablemente en el revelado final, proporcionando así más inestabilidad a la imagen y mayor dramatismo. En realidad la foto original le salió a Smith un poco inclinada, y en vez de ampliarla con la línea del horizonte paralela al borde, la inclinó aún más. Así el mensaje visual de discusión se aumenta, como si la foto hubiese sido difícil de sacar debido a la pelea. Pero no es esa la realidad, sencillamente el encuadre le salió un poco mal, aunque el enfoque $\mathrm{y}$ el instante fueron apropiados.

Todas las fotos son de seres humanos. Además, todas menos una (la 11, del joven con un arado romano) incluyen textos informativos, de manera que el lector del "Spanish Village" puede obtener una información relativa - a menudo personalizadora- sobre la vida cotidiana del pueblo, hacia el final de la primavera y los primeros días del verano. Las imágenes sugieren una vida de lucha y de fe. Hay pobreza, escasez, los niños y las mujeres van descalzos, la ropa sucia y muy remendada, las condiciones higiénicas parecen malas, apenas hay electricidad en la mitad de las casas, se sugieren enfermedades y muerte. El retrato de "El Médico" (sic en el original, foto 4), que aparece llevando un aparato metálico con asa en la mano, se explica con el pie siguiente: "Dr. José Martín realiza sus visitas con linterna para poder iluminar las casas de los pacientes. Lleva a cabo cirugía sencilla, manda a los enfermos más graves a la ciudad de Cáceres, y trata una gran cantidad de casos de tifus". El médico está en la calle con bata no muy blanca, y estetoscopio colgado al cuello. El estado 
de la calle es malo, y los muros y puertas aparecen en condiciones casi ruinosas. Al fondo de la calle se ve un niño que parece estar desnudo. Al lado de esta foto, en la misma hoja, se ve otra pequeña, titulada "Trabajo de niño pequeño" (foto 5). Vemos a un niño con un escobón (sin mango) en la mano, recogiendo excrementos de animales (seguramente de caballerías) de la calle en un cesto, estando descalzo. En el texto se señala: "El hijo menor de la familia Curiel, Lutero, de 5 años de edad, recoge estiércol de la calle en la puerta de su casa. El estiércol se guarda con cuidado para utilizarlo como abono, y será repartido entre las ocho parcelas que la familia alquila o posee, y que están unas millas a las afueras del pueblon. Smith, en una carta posterior a su estancia en Deleitosa, escribe: "Lo que más recuerdo de andar por el pueblo es la cantidad enorme de estiércol, tanto de animales como de seres humanos, en las calles, y los millones de moscas devorándolo, así como al pan que tratábamos de comer" (citado en Hughes 1989: 261). Sin embargo, el reportaje final no incluyó una foto de un niño defecando, en cuclillas, en mitad de la calle que había sido seleccionada por Smith.

Es posible imaginar el impacto que en esos años tienen que haber causado estas fotos en el público norteamericano. Casas mal acondicionadas, estiércol en las calles, restos de comida sobre el suelo, tifus, personas descalzas, algunos niños totalmente desnudos, adultos desdentados, etc. Las fotografías, junto con los textos de los pies, proporcionan una imagen pobre y triste de la vida cotidiana de un pueblo español. A pesar de ello, parece que Smith nunca estuvo contento con "Spanish Village", porque consideró que los editores de Life habían mutilado o transformado sus objetivos políticos. No trataba de presentar una pobreza digna, de la que hay que compadecerse, como es el caso en los estudios clásicos de Jacob A. Riis de 1890 (1971), los de Dorothea Lange, o de Walker Evans, en el proyecto para la Farm Security Administration, sobre la depresión económica, dirigido por Roy Stryker (Lange 1989, Evans 1973); o más modernamente por Magnum, sobre todo los de Sebastião Salgado (1988, 1993). Por alguna razón equívoca, Smith pretende mostrar una población pobre que hay que rechazar, un pueblo en que los habitantes mismos parecen culpables. Smith yerra el tiro: en vez de criticar el régimen de Franco, termina culpabilizando a la propia población que sufre la dictadura. Cae asi en la trampa del síndrome de blaming the victim. Los lectores internacionales del reportaje de Life tuvieron que asombrarse de que se considerase a la población de Delitosa culpable, sucia y atávica. La mayoría de los fotográfos que retratan la pobreza lo hacen para contribuir con ayuda internacional, para generar sentimientos de simpatía, para compadecerse, para ayudar. Smith pretendió hacerlo al revés. La 
explicación de su conducta está quizás en el tópico de la leyenda negra sobre España (de Miguel 1998).

Smith parece obsesionado con la Iglesia católica, que consideraba entre las instituciones más autoritarias y negativas del mundo. Varias de sus fotografías del proyecto de Deleitosa estaban sacadas con la idea de criticarla, y oponerse a su política de limitar la libre expresión de otras religiones. Los editores de Life, por no ofender a la Iglesia católica ni a los políticos estadounidenses que buscaban ayuda financiera para Franco, optaron por no elegir fotos que expresaran esa línea. El texto de pie de foto del "Señor Cura" (foto 6) es el opuesto al significado que seguramente Smith quería darle. Las fotos de "Spanish Village" que representan el tema de la religión expresan, más bien, la fe de los habitantes de Deleitosa en vez de representar a la Iglesia católica como una institución represora.

Los textos podrían haber sido utilizados para expresar las ideas de Smith, pero los editores de Life dirigen conscientemente la atención hacia otra línea. Willumson (1992: 125) explica la forma en que en algunos casos los textos fueron transformados: “Por ejemplo en la primera fotografía [la de Lorenza Curiel saliendo de casa hacia la iglesia, el día de su primera comunión] el fotógrafo capta el contraste entre el vestido blanco y bien arreglado, el velo, y los zapatos [de la niña de la primera comunión], en un lugar en donde todos los demás van descalzos. Hasta la madre de la niña [...] va descalza». En lugar de enfatizar, mediante el pie de foto, que la Iglesia católica española anima a la gente a gastar su poco dinero en comprar vestidos caros para celebrar los sacramentos, "el pie de foto se utiliza para demostrar el enfoque y la importancia de la fe religiosa en la vida de esta genten.

A pesar del intento de no ofender a la Iglesia católica, ni siquiera a la dictadura franquista, los editores de Life no convencieron al público español. El 4 de junio de 1951 se publicó la edición Life International con "Spanish Village." Al mes siguiente se publicaron en España dos críticas muy duras. La primera en la revista Semana (en el número del 24 de julio de 1951) acusó a Smith de ser sensacionalista y de elegir un lugar, Deleitosa, no representativo del país (Fernández Flórez 1951). En Mundo Hispánico (julio 1951: 21-29), el autor, Gaspar Gómez de la Serna, concede que la España rural es un ámbito en que perduran formas antiguas de vivir, tales como las que están representadas en "Spanish Village", pero que Smith había ignorado el contexto histórico de estos pueblos y los adelantos logrados por el resto del país. El fotógrafo Robert Frank, durante su visita a Valencia en 1952, llama la atención en una carta a Smith: «iiEn España, la revista Life - gracias a tu ensayo "Spanish Village" - se 
conoce como un periódico comunista!! Más de una vez me ha preguntado la policía si trabajo con Life y si conozco a E. Smith".

La fotografía suele admitir una interpretación múltiple. Las fotos de Smith son inquietantes y pretenden comunicar un mensaje, aunque lo hacen de forma confusa y contradictoria. No queda claro lo que denuncian o denigran. El mensaje más directo es que España vive en 1950 como en la Edad Media. Pero ese mensaje debería invitar a una ayuda masiva de recursos, y no sólo a una crítica del gobierno. Deleitosa se presenta como una pobreza indigna (lo contrario de otros proyectos anteriores sobre la pobreza digna, por ejemplo sobre la depresión económica en Estados Unidos). Los habitantes de Deleitosa aparecen sutilmente como culpables en vez de inocentes. A su vez la crítica social incorporada en "Spanish Village" es demasiado leve como para cumplir con los fines de Smith, pero demasiado dura para los gustos de la dictadura española. Las fotos están cortadas, ampliadas de forma peculiar, escogidas entre miles para proporcionar un significado determinado. A pesar de esos defectos, "Spanish Village" se considera en el mundo del fotoperiodismo como el mayor logro del género de reportaje fotográfico. Como documento etnográfico, el trabajo de Smith tiene un mérito todavía no reconocido por el mundo antropológico o sociológico.

\section{FOTOPERIODISMO COMO ETNOGRAFÍA}

Como fotoperiodista, Smith se introducía en ambientes muy diferentes al lugar en que nació y creció en Estados Unidos, el estado de Kansas en el centro -el middlewest $-{ }^{26}$. En ese sentido, no era muy diferente de los antropólogos de su época. El antropólogo típico de los años cincuenta investigaba sobre todo en tierras exóticas y lejanas, y presentaba sus resultados mediante un texto escrito. El fotoperiodista investigaba y elaboraba el reportaje, a menudo también en lugares remotos, pero mediante imágenes fotográficas. Bastantes veces el antropólogo sacaba fotos como manera de recordar; y el fotoperiodista escribía algo de texto con finalidad similar. Imagen y texto, los dos medios, eran necesarios para documentar y comprender la vida de pueblos diferentes a los ya conocidos.

26 Es difícil imaginar la reacción que les produciría a los habitantes de Deleitosa la figura y porte de W. Eugene Smith; sobre todo si apareció vestido como en la foto que se puede ver en el libro de Glenn G. Willumson (1992: 47), realizada en 1948 por Robert Harrah: Smith aparece con una camisa que tiene el cuello, pechera, y puños bordados de flores, y está fumando en boquilla. Es probable que el rechazo fuera casi total. 
Se necesitaban también para demostrar al público, por laico o profesional que fuera, la autenticidad y veracidad del trabajo presentado.

En su trabajo sobre Deleitosa, Smith realizó esfuerzos para entender la sociedad, economía y cultura, tanto española como de ese pueblo cacereño. Cualquier investigador que examine con detenimiento el Archivo W. Eugene Smith en el Centro de Fotografía Creativa, en la Universidad de Arizona, quedará impresionado por la cantidad y extensión de apuntes, cartas, cuestionarios, contactos, y fotografías recopiladas por Smith como resultado de su trabajo en Deleitosa ${ }^{27}$. En realidad Smith pasó menos de un mes allí (no pudo fotografiar más de 19 días en total). En tan poco tiempo, logró más material que muchos alumnos de postgrado - $\mathrm{y}$ etnógrafos en general- recopilan en un año entero ${ }^{28}$. Todo eso a pesar de que Smith no hablaba español.

Es arriesgado reconstruir la manera de trabajar de Smith. Por lo que está actualmente en el archivo, parece que casi toda la investigación etnográfica se realizó por medio de cuestionarios. Entró en España acompañado por Nina Peinado, residente entonces con sus padres refugiados en París, quien le sirvió de intérprete. Smith planteó una serie de preguntas, escritas a máquina. Cada hoja, o grupo de hojas, trataba un tema en concreto; por ejemplo, agricultura, salud, educación, entre otros. Algunas hojas preguntaban sobre determinados oficios e instituciones, como la Guardia Civil, la Iglesia católica, o los maestros. El trabajo de Nina Peinado consistía en hablar con los vecinos y apuntar las respuestas en los espacios en blanco, dejados entre una pregunta y otra. Parece que Smith siguió dos puntos de partida diferentes al plantear sus preguntas. Por un lado, investigó temas generales sobre el pueblo, que le proporcionarían información sobre el contexto general. Por ejemplo, escribió una lista de 24 dudas sobre España, entre ellas las siguientes:

¿Quién tiene que pagar a Hacienda? Es decir, un resumen del sistema de impuestos y Hacienda.

¿Qué porcentaje de la tierra se puede cultivar?

¿Qué proporción de la población tiene tierras en propiedad?

¿Existen tasas de paro en la ciudad y en los pueblos, y si existen cuáles son esas tasas y cuándo fueron recopiladas?

¿Qué tipo de comida está destinada a la importación y a la exportación?

27 Center for Creative Photography, The University of Arizona, Tucson, Arizona 85721, Estado Unidos de América, tel. (602) 6217968.

28 En nuestro primer trabajo de campo en Deleitosa, en abril de 1998, en tres días de trabajo realizamos más de seiscientas fotos. En la actualidad trabajamos sobre ese material gráfico y planificamos una segunda visita al pueblo. 
¿Cuántas personas murieron durante la Guerra Civil y cuál era la población [de España] en aquella época?

¿Qué proporción de la población es católica y qué porcentaje de otras religiones? ¿Cuál es el sueldo medio de una persona en la ciudad, en el pueblo, y de un labrador?

¿Cuáles son las reformas agrícolas iniciadas por Franco?

¿Cuáles son los precios, tanto en la ciudad como en los pueblos, de algunos recursos básicos como carne, leche, ropa, pan, etc.?

Precio oficial del trigo este año. El año pasado.

Smith iba investigando y reformulando estas preguntas generales (y muchas otras) durante sus tres meses de estancia en España, desde el 5 de mayo al 8 de julio de 1950. La otra línea de investigación se desarrolla en base a las fotografías específicas que sacaba y que, por lo visto, le interesaban más. El material de encuesta, actualmente en la Universidad de Arizona, demuestra un interés detallado en todo lo que veía. Por ejemplo, en el cuestionario titulado "Funeral", que parte de las impresiones que figuran en la hoja de contacto sobre el velatorio referente a la foto 17 , la última de "Spanish Village", Smith plantea 25 preguntas sobre el velatorio, el difunto y su familia. Entre esas preguntas están las siguientes:

Excepto en el caso del hijo (¿cuántos son?), ¿cómo es que sólo había mujeres en la casa mientras el difunto esperaba el entierro?

¿Quiénes eran las mujeres que acompañaban al difunto?

¿Hay una serie de plegarias específicas, o siguen un ritual pautado?

¿Por qué tenía que irse el hijo a Trujillo antes del entierro del padre?

¿Por qué no había mujeres en el cementerio ni en la procesión al cementerio?

¿Las personas que cavan el hoyo son voluntarios?

Sobre el mismo difunto, de la foto 17 , Smith escribe estas preguntas:

Nombre, edad del difunto.

Nombres de la mujer, hija, e hijo; ¿quién es nuestro amigo?

¿Cuándo quedó paralítico ese señor?

¿Cuándo se rompió la pierna?

¿Cuánto tiempo pasó en el hospital, y dónde?

Los cuestionarios abarcan temas amplios de la cultura, sociedad y vida económica del pueblo. No sorprende que la población de Deleitosa, las personas que figuran en los cuestionarios, contestaran siempre de forma breve. Smith sacó mucho provecho de esos cuestionarios y del trabajo de Nina Peinado. Todas las respuestas están redactadas por ella, una mujer de 20 años apenas preparada para una tarea antropológica de ese tipo. Los cuestionarios, con sus respuestas, son similares -aunque a una escala distinta- a la gran encuesta de los pueblos españoles, patrocinada en 1901-1902 por el Ateneo de Madrid (Lisón Tolosana 1971). 
Como resultado de todas sus investigaciones en Deleitosa, Smith presentó a Life un informe escrito. Ese documento, de unas 45 páginas de extensión, abarca temas diversos, tales como la historia del pueblo, explicaciones de las fotografías seleccionadas para la revista, descripción de los habitantes que habían sido fotografiados, e información sobre la manera de trabajar de su equipo. El documento refleja también los objetivos políticos e ideológicos de Smith. El fotógrafo explica a los editores de Life: “El préstamo a Franco, que en estos momentos está considerando Estados Unidos, espero que sea para comprar fertilizante. La gran mayoría de las personas con las que he hablado -incluso las que apoyan al régimen franquista - creen que cualquier préstamo de Estados Unidos no sería beneficioso para la población española, sino que sería destinado por las autoridades con poder para continuar con ineficacia y prácticas corruptas, puesto que el Gobierno se ha mostrado incapaz de manejar bien los asuntos económicos de España".

En conjunto, las fotografías y textos de Smith ofrecen una visión de la vida cotidiana de Deleitosa equivalente a la de un etnógrafo de la época. Como cualquier etnógrafo, distorsiona - consciente e inconscientementelo que ve y fotografía. Ted Castle, su ayudante, manifiesta que el intento de Smith uera mostrar lo hijo de puta que era Franco, y lo nefasto del vínculo entre la Guardia Civil, Franco, y la Iglesia [católica], unidos los

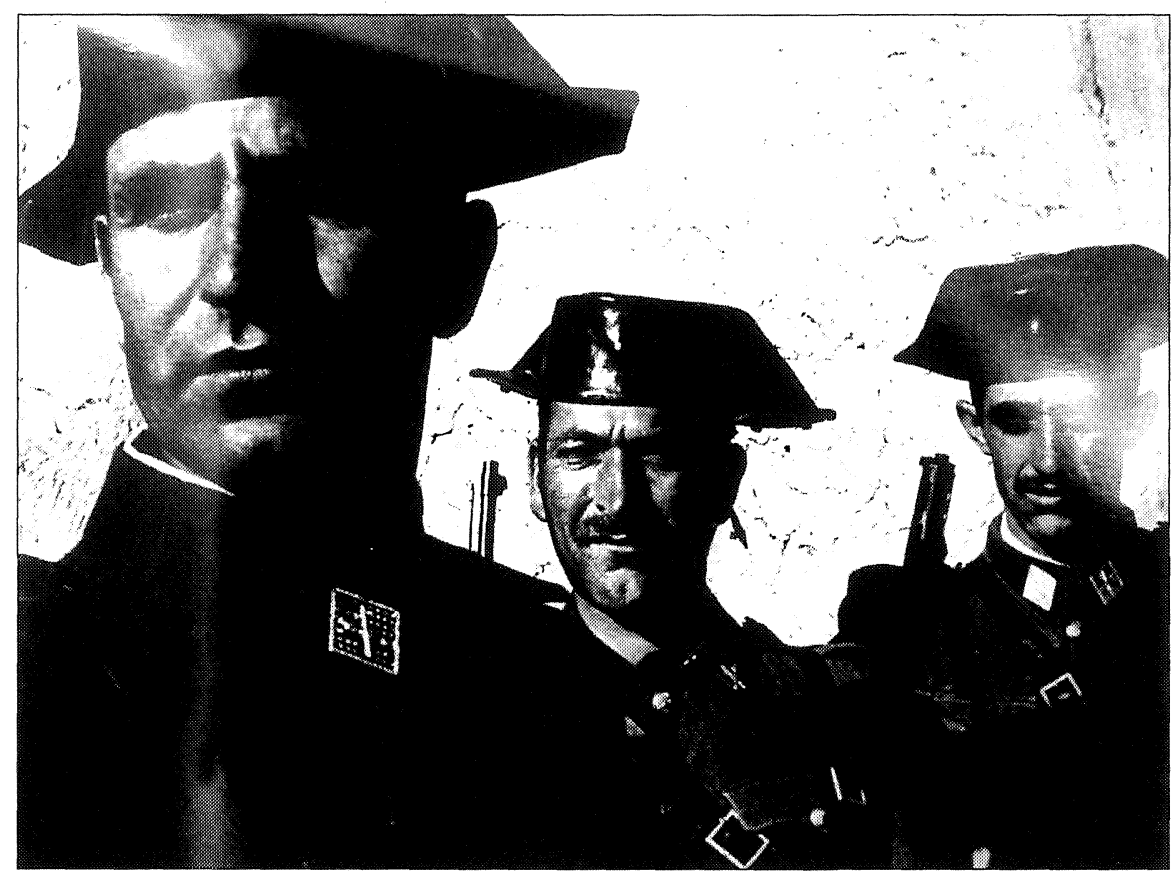


tres contra los pobres" (citado en Hughes 1989: 254). Una de las fotos más famosas que tomó es un retrato de tres guardias civiles, de uniforme, con tricornio y armados (con fusil mauser y con metralleta) que ocupa casi dos hojas del reportaje "Spanish Village. El pie de foto explica: "Estos hombres severos, aplicadores de la ley a nivel nacional, son la policía rural de Franco. Patrullan en el campo, y son temidos por la población en los pueblos, que además también tienen policía local.

La foto de los tres guardias civiles es llamativa, entre las más importantes obtenidas por Smith durante toda su carrera. Muestra la imagen de tres guardias duros, feroces, con un rictus de crueldad. Según Ted Castle - presente en el momento en que Smith sacó la foto- "Los tres hombres de la Guardia Civil estuvieron cerrando los ojos por el sol fuerte que les daba directamente en los ojos, y ellos se quejaban de esto. Pero Gene les decía, mediante la traducción de Nina, _la luz les bace parecer más fuertes, poderosos" (citado en Hughes 1989: 254). En lugar de invitarles a ponerse a la sombra, Smith sacó la foto a pleno sol, lo cual le proporcionó el impacto visual que él buscaba. Realizó una serie, de varias docenas, de fotos de estos tres guardias civiles. Esta foto -escogida entre otras muchas- está cortada, y revelada para acentuar el contraste blanco/negro, incluso el reflejo del sol en el fusil mauser, la metralleta, los tricornios, y las chapas de la Benemérita ${ }^{29}$. De todas las fotos de la serie, ésta es en la que los tres parecen más serios, más fieros, malencarados, y duros. Ha sido cortada por los cuatro laterales (sobre todo el lateral derecho y el superior) para acentuar el dramatismo y eliminar el contexto ${ }^{30}$. Es un contrapicado (Smith la tuvo que tomar agachado) que además magnifica la estatura de los guardias civiles, sobre todo del primero ${ }^{31}$. Las grietas de la fachada de la casa (seguramente era el antiguo cuartel) simulan casi un decorado. Está claro que el fotógrafo deseaba lograr un aspecto duro y desagradable, y lo consigue. Los tres aparecen con los ojos entornados, en una cierta actitud de dolor o dureza. El sol les está dando de lleno en las pupilas (jsol de julio en Extremadura!). El negro del charol de los tricornios se refleja en blanco. Es la foto típica, esperada por los lectores

29 Se trata del negativo 16 de la hoja de contacto publicada por Willumson (1992: 119).

30 Quizás también fue cortada para eliminar la forma de la sombra sobre el tercer guardia civil (el más alejado de la cámara) que seguramente preocupó mucho a Smith durante el revelado. No había forma de hacer desaparecer esa sombra, pero sí al menos de reducir su formato. La foto corresponde al negativo 16, es decir es la cuarta foto que toma de ellos.

31 Son tres varones, obviamente. En la actualidad el cuartel de la Guardia Civil de Deleitosa está dirigido por un sargento, y entre los agentes hay una mujer. 
extranjeros, de la Guardia Civil durante la dictadura de Franco. Se ajusta al tópico establecido, aunque para lograrlo Smith tuviera que realizar docenas de tomas, sacando fotos alrededor de ellos, manipulando luego el negativo y la ampliación en el revelado.

La mayoría de las fotos que aparecen en "Spanish Village" fueron sacadas de manera más o menos teatral, es decir, planeada, previsualizada, y no espontánea. Hasta en la misma foto de gran angular, que muestra la entrada del pueblo, con varios vecinos y animales realizando sus actividades cotidianas por dos largas calles (es la foto 2: "En las afueras"), Smith tardó mucho tiempo en prepararse antes del momento de disparar. Insistía en que quería ofrecer un panorama verídico del pueblo. La posibilidad era convertir a Deleitosa en un escenario que, de una manera u otra, ya tenía su guión redactado. Pero esa foto (2) no representa realmente las afueras del pueblo sino su entrada por la carretera principal: la que va de la carretera nacional - hoy Autovía de Extremadura - pasa por Deleitosa y conduce hacia los pueblos de Robledollano y Retamosa. Es la única carretera que pasa por Deleitosa. La perspectiva casi idéntica puede verse medio siglo después, ya que se conserva la misma estructura de calles ${ }^{32}$. En la esquina de la izquierda existe actualmente un bar-café-discoteca cuyo nombre es La Oficina; con una máquina de cocacolas frías en la puerta.

En la foto original, de hace medio siglo, la estructura de las casas es de un sólo piso, con muros y tejados en malas condiciones. Las chimeneas alargadas son peculiares. Se distinguen los aislantes o pitorros de porcelana blanca, con dos cables, para la conducción de la electricidad. Las casas tienen puertas de madera y a menudo bancos de obra para sentarse en el muro frontal. Se cuentan hasta 25 personas en ese momento del mediodía en las dos calles, por lo menos seis burros, una gallina a la puerta de la casa, un perro, y varios niños. Dos de ellos están sentados en el suelo, en mitad de la plaza o intersección. El suelo es de tierra, mal empedrado, irregular y en malas condiciones. La impresión es teatral, de decorado, pero ciertamente medieval ${ }^{33}$. El único sistema de transporte que se observa es el burro. La estructura es de casuchas, algunas casi parcialmente derruidas. Sólo destaca la iglesia, el campanario, al fondo. La foto comunica también una idea de convivencia de seres humanos con animales, en el mismo territorio doméstico y público a la vez. Uno

32 Pero en la actualidad no hay la posibilidad de realizar ese picado. No nos queda claro cómo lo consiguió Smith; seguramente existía una casa al otro lado de la carretera. Quizás tomó la foto utilizando una escalera elevada, o de pie sobre un coche, o similar.

33 Alguno de los fotogramas del pueblo Villar del Río, de la película Bienvenido Mister Marshall (1953) es similar a esta foto. 
de los burros parece salir de una de las viviendas, como recibiendo a los tres burros que llegan ${ }^{34}$. No se observan tiendas ni ningún detalle de progreso; sólo algún poste de luz, pequeño, en estado ruinoso. Si no fuese por eso la foto podría ser de la Edad Media. Precisamente eso es lo que le confiere una fuerza especial. Smith fue capaz de fotografiar la época medieval, en el corazón de España.

Cualquier etnógrafo de comunidades rurales españolas puede aprender mucho de las fotografías realizadas por Smith en junio/julio de 1950. Sirven tanto para estudios etnohistóricos como para investigaciones del cambio social. Además de perseguir su objetivo político y artístico, Smith logró una reconstrucción en imágenes de la vida cotidiana de un pueblo extremeño. Otros fotógrafos de la época trabajaban sobre costumbres populares, cultura material, paisajes y pueblos, trajes típicos, etc. Pero nadie, ni español ni extranjero, realizó algo similar. El análisis de un sólo pueblo, tal y como lo desarrolló Smith, suponía estudios etnográficos de comunidades que apenas habían empezado en los años cincuenta. Su fotoperiodismo es equivalente, en el campo tecnológico y artístico, a las investigaciones antropológicas de comunidad realizadas mediante trabajo de campo.

Hay otros puntos de comparación. Como cualquier etnógrafo, Smith procuraba realizar un estudio justo, equilibrado y fiel de la realidad. Pero se observa Deleitosa - y España en general- a través de los ojos del fotógrafo, lo cual implica forzosamente un elemento de subjetividad. La cámara fotográfica supone un instrumento adicional con limitaciones ${ }^{35}$. Además las fotos son en blanco y negro. En ese sentido, Smith no era diferente de cualquier etnógrafo de la época, una época, por cierto, en que había muchísima menos conciencia de las distorsiones posibles e inevitables en los estudios etnográficos de la que mantenemos hoy en día.

Smith no funcionaba como un típico observador participante. Para empezar, pasó 19 días en Deleitosa, en lugar del año completo que se considera el período mínimo para un etnógrafo profesional. A pesar de lo que había manifestado a los editores de Life, Smith no hablaba español; tuvo que trabajar mediante intérprete, una práctica impensable para un antropólogo que pretende comprender la vida cotidiana. Sin embargo,

3. Se pueden contar por las sombras del mediodía.

35 Supone limitaciones por el hecho de ser una cámara fotográfica, no por ser Leica, que en aquellos momentos representaba ya un avance considerable. Las fotos realizadas por nosotros en el trabajo de campo de abril de 1998 están tomadas también con una Leica, en este caso una M6, con objetivos Summilux (de 1,4/50 mm., y de $1,4 / 35 \mathrm{~mm}$. ASPH), todas con film blanco y negro Tmax 400 ASA. 
en cuestiones de lengua, no era diferente de muchos antropólogos e investigadores que trabajan con pueblos no indoeuropeos, quienes casi nunca logran dominar el idioma de los sujetos de estudio. Tampoco variaba tanto su estancia en Deleitosa de las estancias típicas de investigadores tales como folkloristas, etnógrafos nativos de la región de estudio y antropólogos norteamericanos que, en la época de Boas, realizaban el trabajo de campo entre tribus de indígenas durante los fines de semana.

Mediante la fotografía, Smith trató de influir en la política estadounidense. Esta finalidad le urgía a producir imágenes de Deleitosa llamativas en el sentido tanto artístico como emocional. Es bien sabido que las imágenes publicadas en "Spanish Village" fueron sacadas y reveladas por él mismo. Tuvo también la posibilidad de elegir varias imágenes (113 precisamente: 57 con comentario extenso, y 56 con pie de foto breve) para presentarlas como posibles fotos para publicar. Entre las 57 primeras figuran 16 de las 17 fotos de "Spanish Village". Entre las elegidas por los editores, había otra de la segunda selección de Smith que llamó mucho la atención de Life: la de una mujer hilando (foto 16). Quizá sea la fotografía más famosa de todas las que sacó en Deleitosa. Pero era demasiado estética para su gusto; la selección de la revista respondió más a criterios estéticos que políticos. Se observa una mujer hilando lino (que se producía en la región) sentada sobre una estera rayada como las que todavía abundan en el pueblo. Al fondo, otra mujer cose. Están en la calle, a la puerta de casa. La foto tiene movimiento, y está muy bien compuesta. A pesar de su apariencia medieval, comunica serenidad, simpatía, pobreza digna, algo que seguramente no pretendía el autor.

Al final, Smith no quedó satisfecho del reportaje publicado. Consideró que los editores de Life habían transformado su proyecto. Incluso la reacción negativa de las revistas oficiales españolas (que estaban lógicamente bajo censura gubernamental) no le convenció de que el reportaje había afectado a la población de la manera en que él esperaba. Quizá fue que Smith no se fiaba del pueblo español porque no lo conocía. En realidad las fotos carecen de empatía, incluso las de la familia Curiel. Están claramente sacadas por un outsider, por una persona que se considera extraña al pueblo, e incluso a la cultura. Smith llegó a Deleitosa para realizar un estudio ya pensado ideológicamente antes de empezar a disparar su Leica. Respecto a esto, no es diferente tampoco de muchos etnógrafos, guiados en sus investigaciones por los esquemas teóricos rígidos, codificados. Las mismas fotografías publicadas en The People of the Sierra (PittRivers 1954) - la etnografía clásica de Julian Pitt-Rivers sobre Alcalá de la Sierra- se conforman a la idea del "Otro" primitivo español que regía en los años cincuenta, época en que se llevó a cabo el trabajo de campo en 
Grazalema (Brandes 1997). Quizás el trabajo fotográfico de Smith haya que interpretarlo en relación con el de otros fotógrafos importantes de la época sobre España, sobre todo el Séville en fête de Brassaï en 1954, Henri CartierBresson por los mismos años (publicado en 1982), Inge Morath entre 1953 y 1957 (1994); posteriormente los trabajos de Cristina García Rodero en España oculta (1989), y el proyecto A Day in the Life of Spain (Smolan y Cohen, eds. 1987) ${ }^{36}$.

Tanto el fotoperiodismo como la etnografía enseñan y engañan a la vez. Ambos construyen la realidad social. Pero al mismo tiempo son espejos que permiten luego analizar al observador (Buxó y de Miguel, eds. 1998). Como un criminal, el fotógrafo dispara (la cámara) y desaparece. Deja a los espectadores ante sus fotos, en la misma posición que antes él ocupó. Con un poco de imaginación no sólo se puede aprender mucho sobre Deleitosa, sino sobre W. Eugene Smith, sus deseos ocultos y fobias. Se puede aprender también de la mirada norteamericana sobre los demás países en plena época del "sueño americano". Pero los fallos indudables del proyecto fotográfico de W. Eugene Smith no invalidan la posibilidad de aprender de su trabajo, tanto en relación con la realidad que pretende fotografiar (Deleitosa), como sobre su propia persona: Los antropólogos y sociólogos de los años noventa apenas empiezan a aprovechar intelectualmente las posibilidades de la antropología visual. Smith representa esos hombros de los gigantes que mertonianamente permiten ver más lejos.

Quizás dentro de cincuenta, o de cien años, alguien que lea nuestro artículo vuelva a Deleitosa a seguir investigando la realidad social: con papel-y-lápiz y cámara fotográfica. Cuenta con toda nuestra ayuda y entusiasmo.

\section{BiBLIOGRAFÍA}

BRANDES, Stanley, 1997: "Photographic imagery in the ethnography of Spain", Visual Anthropology Review, 13, 1-13.

Brassaï, 1954: Séville en fête, Paris: Robert Delpire. Textos de Dominique Aubier. [Brassaï es el nombre con el que se conoce en fotografía al fotógrafo Gyula Halász (18991984)].

Buxó, María Jesús, y Jesús M. DE Miguel (eds.), 1998: De la investigación audiovisual, Barcelona: Proyecto A.

Cartier-Bresson, Henri, 1982: Henri Cartier-Bresson, Paris: Centre National de la Photographie. [Nueve de las 63 fotografías son sobre España en los años cincuenta].

36 El de Brassaï es un estudio muy difícil de conseguir por estar agotado y de edición limitada. Pero merece un estudio comparativo. 
Europalia, 1985: Aspecten van Spanje: Imágenes, Hasselt, Bélgica: Cultureel Centrum. Evans, Walker, 1973: Walker Evans: Photographs for the Farm Security Administration, 1935-1938, New York: A Da Capo Paperback. [Es parte del catálogo de la Farm Security Administration Collection en la Library of Congress, en Washington DC.].

FERNÁNDEZ FlóREZ, W., 1951: “Frente a una información amañada y ridícula: De la leyenda negra a la foto negra sobre Españan, Semana (24 julio).

Fundación Gregorio Marañón (ed.), 1993: Viaje a las Hurdes: El manuscrito inédito de Gregorio Marañón y las fotografias de la visita de Alfonso XIII, Madrid: El País Aguilar.

García Rodero, Cristina, 1992: España oculta, Barcelona: Lundwerg. [Selección de 126 fotos realizadas entre 1975 y 1989].

Gómez de la Serna, Gaspar, 1951: "Carta al editor de Life", Mundo Hispánico, 40. [E] subtítulo es "He aquí una réplica, suscrita por un joven escritor español, a la revista Life de N. Y., por una tendenciosa información acerca de la vida rural en España". Incluye una traducción al inglés: "Letter to the Editor of Lifes (en la página 18)].

HUGHES, Jim, 1989: W. Eugene Smith: Shadow and substance, New York: McGraw Hill. InstiTUTO GeOGRÁFICO NACIONAL, 1997: Mapa topográfico nacional de España: Deleitosa, Madrid: Ministerio de Fomento. Mapa 680-II a escala 1:25.000.

JoHNSON, William S. (ed.), 1981: Eugene Smith: Master of the photographic essay, New York: Aperture. [Prólogo de James L. Enyeart. Reproduce 99 fotos del proyecto Deleitosa, en las pp. 73-82. Se ha manejado la copia 113 de la edición numerada del librol.

LANGE, Dorothea, 1989: Dorothea Lange, Paris: Nathan Image.

LISÓN TOlosana, Carmelo, 1971: "Una gran encuesta de 1901-1902 (Notas para la historia de la antropología social en España)", en Antropología social de España, Madrid: Siglo Veintiuno, pp. 97-172.

LÓPEZ MONDÉjAR, Publio, 1997: Historia de la fotografía en España, Barcelona: Lunwerg.

Miguel, Jesús M. de, 1998: Estructura y cambio social en España, Madrid: Alianza Editorial.

MORATH, Inge, 1994: Inge Morath: España en los cincuenta, Madrid: Artecontexto. [Fotos de la fotógrafa austríaca entre 1953 y 1957].

Muro, Matilde y M. Teresa P. ZuBizARRETA, 1987: La memoria quieta: La fotografía en Trujillo hasta 1936, Barcelona: César Viuera Editor.

MUNDO HISPÁNICO, 1951: "Deleitosa de Life, la España contra la que España lucha y los Deleitosa de la nueva España", Mundo Hispánico, 40, pp. 21-29. [Incluye el reportaje: "Bernuy: La vida en un nuevo pueblo español"].

PINILLA DE LAS HERAS, Esteban, 1996: La memoria inquieta: Autobiografía sociológica de los años difíciles 1935-1959, Madrid: Centro de Investigaciones Sociológicas.

PITT-RIvers, Julian, 1954: The People of the Sierra, New York: Criterion.

PRICE, Mary, 1994: The photograph: A strange, confined space, Stanford: Stanford University Press.

QuiJADA, Domingo, 1998: Deleitosa: Aproximación al conocimiento de su bistoria, Deleitosa, Cáceres. [Fotocopia del informe de marzo de 1998. Domingo Quijada firma como profesor de Geografía e Historia, "Cronista Oficial de Navalmoral". Fotocopia realizada por el Ayuntamiento de Deleitosa, gracias a Esperanza Mateos Trujillo].

RiIS, Jacob A., 1971: How the other half lives: Studies among the tenements of New York, New York: Dover, 1971. [ La edición original es de 1890, reeditada en 1901 y 1947]. 
SAlgado, Sebastião, 1988: Sabel: El fin del camino, Madrid: Comunidad de Madrid. - 1993: Workers: An archeology of the industrial age, London: Phaidon Press.

SмIтH, W. Eugene, 1951: "Spanish village: It lives in ancient poverty and faith", Life, 30, n. ${ }^{\circ} 15$ (9 de abril), 120-129.

- 1983: W. Eugene Smith, Paris: Centre National de la Photographie. [2." ed.].

- 1993: W. Eugene Smith: His photographs and notes, New York: Aperture.

SMOLAN RICK, y David COHEN (eds.), 1987: A day in the life of Spain, New York: Collins Publishers. [Se refiere al 7 de mayo de 1987. Selección sobre unas 120.000 fotos]. STEICHEN, Edward (ed.), 1955: The family of man, New York: The Museum of Modern Art.

Willumson, Glenn G., 1992: W. Eugene Smith and the photographic essay, Cambridge: Cambridge University Press.

Este artículo, basado tanto en trabajo de campo como en investigación documental, trata de un episodio fotográfico en la historia española todavía poco reconocido por investigadores españoles: la expedición en junio del 1950 del gran fotógrafo estadounidense W. Eugene Smith y sus dos ayudantes al pueblo cacereño de Deleitosa. El artículo describe los métodos de trabajo de Smith y su equipo; analiza el resultado de este trabajo, es decir, el famoso ensayo fotográfico "Spanish Village", publicado en la revista Life en 1951; mide el impacto social de Smith dentro y fuera de España; y compara la fotografía etnográfica con la periodística.

By relying on fieldwork as well as on library research, the author discusses a photographic event in the modern history of Spain that is little known by Spanish scholars: the expedition in June, 1950 of the great American photographer W. Eugene Smith and his two assistants to the village of Deleitosa, in the province of Caceres. The author describes the methodology of Smith and his team, then analyzes the results of his work, the famous photographic documentary "A Spanish Village", published in LIFE magazine in 1951. He also assesses the social impact of this work in and out of Spain and compares the ethnographic photograph with that used in journalism. 